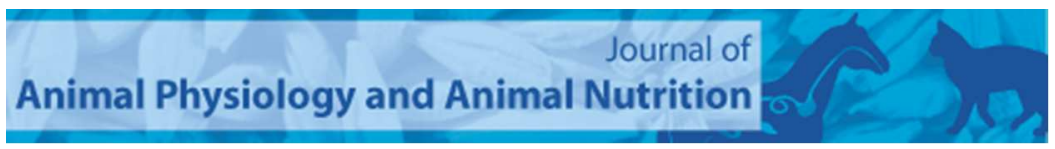

\title{
Rapeseed napin and cruciferin are readily digested by poultry
}

\begin{tabular}{|r|l|}
\hline Journal: & Journal of Animal Physiology and Animal Nutrition \\
\hline Manuscript ID & JAPAN-Feb-16-086.R3 \\
\hline Danuscript Type: & Original Article \\
\hline Complete List of Authors: & $\begin{array}{l}\text { Kasprzak, Miroslaw; University of Nottingham, } \\
\text { Houdijk, Jos; Scotland \'s Rural College, Monogastric Science Research } \\
\text { Centre } \\
\text { Liddell, Susan; University of Nottingham } \\
\text { Davis, Kenneth; University of Nottingham } \\
\text { Olukosi, Oluyinka; Scotland \'s Rural College, Monogastric Science Research } \\
\text { Centre } \\
\text { Kightley, Simon; National Institute of Agricultural Botany } \\
\text { White, Gavin; University of Nottingham } \\
\text { Wiseman, Julian; University of Nottingham }\end{array}$ \\
\hline Subject Area: & napin, cruciferin, protein, rapeseed meal, rapeseed cake, chickens \\
\hline \multicolumn{2}{|c}{} \\
\hline
\end{tabular}

SCHOLARONE ${ }^{m}$

Manuscripts 
3 Title: Rapeseed napin and cruciferin are readily digested by poultry

4

5 Running title: Rapeseed proteins are readily digested by poultry

6

7

8 M.M. Kasprzak ${ }^{1,{ }^{*}}$, J.G.M. Houdijk ${ }^{2}$, S. Liddell ${ }^{1}$, K. Davis ${ }^{1}$, O.A. Olukosi ${ }^{2}$, S. Kightley ${ }^{3}$, G. A. White ${ }^{1}$ and 9 J.Wiseman ${ }^{1}$ 1 School of Biosciences, University of Nottingham, Sutton Bonington, Loughborough LE12 5RD, UK 2 Monogastric Science Research Centre, Scotland's Rural College, EH9 3JG, UK; 3 National Institute of Agricultural Botany, Cambridge CB3 OLE, UK 


\section{Summary}

32 Rapeseed proteins have been considered as being poorly digestible in the gut of non-ruminants. The

33 aim of the study was to assess the digestibility of napin and cruciferin in ileal digesta of broiler

34 chickens, testing sixteen samples of rapeseed co-products with protein levels ranging from 293

$35 \mathrm{~g} / \mathrm{kg}$ to $560 \mathrm{~g} / \mathrm{kg}$ dry matter. Each sample was included into a semi-synthetic diet at a rate of

$36500 \mathrm{~g} / \mathrm{kg}$ and evaluated with broiler chickens in a randomised design. Dietary and ileal digesta

37 proteins were extracted and identified by gel-based liquid chromatography tandem mass

38 spectrometry (LC-MS/MS). Three isomers of napin (a 2S albumin) and nine cruciferins (an $11 \mathrm{~S}$

39 globulin) were identified in the rapeseed co-products, whereas six endogenous enzymes such

40 as trypsin (I-P1, II-P29), chymotrypsin (elastase and precursor), carboxypeptidase B, and $\alpha$ -

41 amylase were found in the ileal digesta. It is concluded that as none of the rapeseed proteins

42 were detected in the ileal digesta, rapeseed proteins can be readily digested by broiler

43 chickens, irrespective of the protein content in the diet.

44

Keywords: napin; cruciferin; protein; rapeseed meal; rapeseed cake; chickens.

47 Correspondence: M.M. Kasprzak, School of Biosciences, University of Nottingham, Sutton Bonington, 
61

62

63

64

65

66

67

68

69

\section{Introduction}

The seed storage proteins of rapeseed (Brassica napus) consist of approximately $60 \%$ cruciferin (known as $11 \mathrm{~S}$ globulin, rich in lysine and methionine), 20\% napin (2S albumin, rich in glutamine, proline, and cysteine), and minor proteins such as thionins, trypsin inhibitor and lipid transfer protein (Berot et al., 2005; Bos et al., 2007). Cruciferin (molecular weight, MW 300-360 $\mathrm{kDa}$ ) consists of six subunits that are arranged as two trimers, held together by hydrogen bonds and salt bridges (Wanasundara and Mclntosh, 2013). The cruciferin subunit of this hexameric assembly ( 50 kDa) contains an acidic or $\alpha$-chain (29-33 kDa) and a basic or $\beta$-chain (20-23 $\mathrm{kDa}$ ), that are linked by single disulphide bond (Schatzki et al., 2014). Napin (MW 13-18 kDa), is a dimer of a large or heavy polypeptide (10-12 kDa) and a small or light (3-6 kDa) polypeptide that are connected by four disulphide bonds (Rask et al., 1998; Wanasundara and Mclntosh, 2013; Schatzki et al., 2014).

Rapeseed co-products are of considerable interest as a protein source in animal feeds due to a high content of protein with a greater content of sulphur-rich amino acids (cysteine, methionine) compared to a standard soybean meal (Wickramasuriya et al., 2015). During rapeseed oil production, whole seeds are de-fatted by hexane extraction producing a rapeseed meal (RSM), or by cold-pressing producing a rapeseed cake (RSC) (Untersmayr and JensenJarolim, 2008). The crude protein content of the co-products may range from 329 to $437 \mathrm{~g} / \mathrm{kg}$ dry matter (DM) (Seneviratne et al., 2011a, b; Maison et al., 2014). However, protein content and individual amino acid levels will vary depending on rapeseed variety and oil extraction method used (Kasprzak et al., 2016). Several studies have shown that rapeseed protein is less digestible (by an absolute decrease of 14-16\%) than soybean protein or casein protein in standard diets (Savoie et al., 1988; Adedokun et al., 2008). This difference in nutritional value of protein is not only attributed to variation in chemical composition between the co-products, but also to the compact structure and relatively high content of disulphide bonds in rapeseed protein. When in vitro models were used, napin was reported to be extremely resistant to pepsin digestion and denaturation caused by heat and low pH (Murtagh et al., 2003; Abeysekara and Wanasundara, 2009; Wanasundara, 2011).

To the best of our knowledge, there is no in vivo study focusing on digestibility of napin and cruciferin in the gastro-intestinal tract of non-ruminants when examining rapeseed proteins. 
91 The aim of the current study was to identify proteins in de-fatted rapeseed co-products, and the corresponding ileal digesta from broilers fed rapeseed diets.

93

Materials and methods

95

96

Rapeseed co-products and diets

97

Thirteen rapeseed varieties were grown and harvested in four different counties in Great Britain

in 2013. Four rapeseed varieties were cold-pressed producing RSC, and eleven rapeseed varieties were softly processed and hexane-extracted producing soft rapeseed meal (SRSM).

The soft processing was used in order to minimise the possibility of overriding the variety variation across the SRSM.

102 The conditioning, seed crushing and hexane extraction was conducted in a pilot plant (Pessac, Bordeaux, France), while cold-pressing was performed at a local plant in Norfolk (United

104 Kingdom) according to previously described methods (Kasprzak et al., 2016). The resulting four RSC and twelve SRSM samples were ground ( $4 \mathrm{~mm}$ sieve) and included in a semi-synthetic diet at $500 \mathrm{~g} / \mathrm{kg}$ as previously published by Kasprzak et al. (2016). The rapeseed co-products were the only source of protein in the diets. Each of the diets also contained, in addition to the rapeseed co-products, wheat starch $(200 \mathrm{~g} / \mathrm{kg})$, glucose $(195 \mathrm{~g} / \mathrm{kg})$, vitamins and minerals (50 $\mathrm{g} / \mathrm{kg}$ ), rapeseed oil $(50 \mathrm{~g} / \mathrm{kg}$ ) and an inert digestibility marker - titanium dioxide (5 g/kg).

112 Day old male Ross Broilers $308(n=192)$ were obtained from a British designated breeder (PD

113 Hook Hatcheries Ltd., Thirsk, UK) and housed in the Animal Facility at the School of Bioscience,

114 University of Nottingham, UK. The chickens were housed in pairs, in cages of $42 \mathrm{~cm}$ tall, $30 \mathrm{~cm}$

115 deep and $37 \mathrm{~cm}$ wide. All bird protocols were approved by the relevant Ethical Review

116 Committee and all experimental conditions followed official guidelines for the care and

117 management of birds.

118 Birds were weighed to ensure that individuals in a pair are as close as possible to each other in

119 terms of weight to avoid any dominance. The chickens were located in pairs of a similar body 120 weight to the cages. Weighing and allocation of birds to cages were prior to feeding the starter 
121 diet and the experimental diets. All chickens were fed a standard commercial broiler starter diet

122 based on wheat and de-hulled SBM with content of protein $190 \mathrm{~g} / \mathrm{kg}$ as-fed (Chick Starter

123 Crumb, Dodson and Horrell Ltd., Northamptonshire, UK) for 14 days. Afterwards, chickens

124 weighing $445 \pm 56.0 \mathrm{~g}$ were allocated to each of sixteen experimental diets $(n=6)$ in a

125 randomized complete block design and fed for eight days. On day 22, birds were culled by

126 asphyxiation with carbon dioxide followed by cervical dislocation to confirm death and the ileal

127 region of the gut was dissected out from the Meckel's diverticulum to the ileal-caecal junction.

128 Ileal digesta were collected from both birds per cage and pooled providing six replicates for

129 each experimental diet. The samples were stored at $-20^{\circ} \mathrm{C}$ until further analysis.

130

131 Analytical methods

132 RSC and SRSM were analysed for dry matter (DM) in duplicate samples weighing 60-65 $\mathrm{g}$ that 133 were dried at $100{ }^{\circ} \mathrm{C}$ in a forced air convection oven. DM of ileal digesta was measured by

134 freeze-drying the ileal content. Total nitrogen was determined using the Dumas method 968.06

135 (AOAC). Crude protein $(\mathrm{CP})$ was calculated as $6.25 \times$ total nitrogen. Amino acid were oxidized

136 with performic acid and further neutralised with sodium metabisulphite (Llames and Fontaine,

137 1994). Then, the content of amino acids was determined by an ion-exchange chromatography

138 for post-column derivatisation with ninhydrin. The content of oil was determined using

139 continuous-wave low-resolution nuclear magnetic resonance spectrometry (EN ISO).

140

141 Solubilisation of proteins from rapeseed co-products and freeze-dried ileal digesta

142 Proteins were extracted from rapeseed co-products and ileal digesta according to a method by

143 Wanasundara and Mclntosh (2013) with a minor modification. Twenty mg of rapeseed co-

144 products or ileal digesta was mixed with $1000 \mu \mathrm{l}$ of acidulated water $(1 \mu \mathrm{S}$ conductance water,

$1452 \% \mathrm{NaCl}$, adjusted with $\mathrm{HCl}$ to $\mathrm{pH}=3$ ) for 2 hours at $20^{\circ} \mathrm{C}$ by rolling (Roller mixer SRT1, Stuart

146 Scientific, UK). Subsequently, the slurry was centrifuged (23.500 g, $20 \mathrm{~min})$ and the supernatant

147 was collected.

148

149 Sodium dodecyl sulphate polyacrylamide gel electrophoresis (SDS-PAGE) 
$15022.5 \mu \mathrm{l}$ of sample supernatant and $7.5 \mu \mathrm{l}$ of $4 \mathrm{X}$ Laemmli buffer with $(0.35 \mathrm{M})$ and without

151 reducing agent (dithiothreitol, +DTT, -DTT) were heated $\left(100{ }^{\circ} \mathrm{C}\right.$ for $5 \mathrm{~min}$ ) and then centrifuged

152 (16.000 g, $10 \mathrm{~min})$. DTT was used to cleave disulphide linkages between cysteine groups in

153 proteins. $15 \mu \mathrm{l}$ of supernatant sample as well as low and high molecular weight standards (10

$154 \mu \mathrm{l}, 1.4-26.6 \mathrm{kDa} ; 15 \mu \mathrm{l}, 10-250 \mathrm{kDa}$, Bio-Rad Laboratories, Hercules CA, US) were loaded onto

155 a 10-20\% Tris/Tricine polyacrylamide gradient gel (Bio-Rad, UK). The electrophoresis was run

156 at $80 \mathrm{~V}$ for $20 \mathrm{~min}$ and $120 \mathrm{~V}$ for $1 \mathrm{~h} 40 \mathrm{~min}$ using Tris/Tricine running buffer (100 mM Tris, 100

$157 \mathrm{mM}$ Tricine, 0.1\% SDS (Bio-Rad, UK). Afterwards, gels were fixed (methanol 40\%, acetic acid

$15810 \%$ ) for $30 \mathrm{~min}$, stained in coomassie Blue (acetic acid 10\%, coomassie blue G $0.25 \mathrm{~g} / \mathrm{l}$ ) for $1 \mathrm{~h}$

159 and destained in $10 \%$ acetic acid solution for at least $3 \times 15$ minutes washes. The images of the

160 gels were recorded (GS-800 calibrated densitometer, Bio-Rad, UK).

161

162 Processing and in vitro tryptic digestion

163 Protein bands were excised from gels using a sterile scalpel into $\sim 1 \mathrm{~mm}^{3}$ cubes, and processed

164 in gel pieces using the robotic liquid handling station (Proteome Works Mass PREP, Waters,

$165 \mathrm{UK})$. The samples were incubated three times in $100 \mu \mathrm{l}$ of de-stain solution (50 mM ammonium

166 bicarbonate, $50 \%$ acetonitrile), and dehydrated in $50 \mu \mathrm{l}$ of acetonitrile for 5 minutes. After the

167 evaporation of acetonitrile, the sample was treated with reducing solution (10 mM DTT, $100 \mathrm{mM}$

168 ammonium bicarbonate) and alkylation solution. Following washing with ammonium bicarbonate

169 and acetonitrile, the microtitre plate containing the gel plugs was cooled to $6{ }^{\circ} \mathrm{C}$ and $25 \mu \mathrm{l}$ of

170 trypsin gold (Promega) was added per well. Sample was diluted to $10 \mathrm{ng} / \mu \mathrm{l}$ in trypsin digestion

171 buffer (50 mM ammonium bicarbonate), subsequently incubated at $6^{\circ} \mathrm{C}$ for a further 20 minutes

172 in order to permit trypsin entry into the gel plugs, followed by incubation at $40{ }^{\circ} \mathrm{C}$ for 5 hours.

173

174 Mass spectrometry and protein identification

175 Samples were analysed by liquid chromatography-tandem mass spectrometry on a Q-TOFII

176 fitted with a nanoflow ESI (electrospray ionization) source (Waters Ltd). Peptides were trapped, 177 desalted and separated on a short pre-column (PepMap C18 reverse phase, 5-mm [Thermo])

178 and delivered on-line to the MS via a CapLC HPLC system. Tandem MS data were acquired

179 using an automated data-dependent switching between MS and MS/MS scanning based upon 
180 ion intensity, mass and charge state (data directed analysis (DDA $\left.{ }^{\mathrm{TM}}\right)$ ). In this automated

181

182

183

184

185

186

187

188

189

190

191

192

193

194

195

196

197

198

199

200

201

202

203

204

205

206

207

208

209 acquisition type of experiment, a method was created in the MassLynx 4.0 software in which charge state recognition was used to select doubly, triply and quadruply charged precursor peptide ions for fragmentation. The collision energy was automatically selected based on charge and mass of each precursor and varied from 15 to $55 \mathrm{eV}$. Protein Lynx Global Server version 2.0 (Waters, Ltd) was used to process the uninterpreted MS data into peak list (pkl) files which were searched against all entries in Swissprot 2014_11, 2015_02 and/or NCBInr 20141208, 20150208, 20150213 databases using the web version of the MASCOT MS/MS ions search tool (http://www.matrixscience.com/). Carbamidomethylation of cysteine and oxidation of methionine were set as variable modifications. One missed cleavage by trypsin was accepted. Other than file type (Micromass pkl) and instrument type (ESI-QUAD-TOF), all remaining search values were the present defaults. Positive identification was based on the Mascot score, significant peptide coverage of the protein sequence.

Results

Content of protein in diets and ileal digesta

The chemical characterisation of rapeseed co-product and ileal digesta is shown in Table 1 (all data on DM basis). The content of CP varied between $293 \mathrm{~g} / \mathrm{kg}$ and $339 \mathrm{~g} / \mathrm{kg}$ in RSC, and ranged from $419 \mathrm{~g} / \mathrm{kg}$ to $560 \mathrm{~g} / \mathrm{kg}$ DM in SRSM. Similarly, total amino acid (TAA) content ranged from $256 \mathrm{~g} / \mathrm{kg} \mathrm{DM}$ in RSC, to $457 \mathrm{~g} / \mathrm{kg}$ DM in SRSM. Thus, the RSC batch was relative low in CP, whereas SRSM was richer in CP. CP level ranged from $109 \mathrm{~g} / \mathrm{kg} \mathrm{DM}$ in ileal digesta of Compass RSC to $164 \mathrm{~g} / \mathrm{kg}$ DM in ileal digesta of Incentive SRSM, respectively. The sum of methionine and cysteine varied from 16 to $34 \mathrm{~g} / \mathrm{kg}$ DM in rapeseed co-products, while the methionine and cysteine content ranged from 7 to $11 \mathrm{~g} / \mathrm{kg} \mathrm{DM}$ in ileal digesta.

Identification of proteins in rapeseed co-products

Across all sixteen rapeseed co-products, the polypeptide profiles of proteins showed the same pattern of protein bands under non-reducing conditions, irrespective of the rapeseed variety and processing method. Similarly, the profiles were almost identical under reducing conditions 
210 across all of the samples. Figure 1 shows a polypeptide profile of proteins in two rapeseed

211 varieties (DK Cabernet, Compass) that were processed by both methods (hexane extraction

212 and cold pressing). Under non-reducing condition, the predominant rapeseed proteins mainly

213 migrated at $\sim 50 \mathrm{kD}$ and $\sim 14 \mathrm{kD}$. Also, two peptides in bands of $\sim 26 \mathrm{kD}$ and one in a band of

$214 \sim 18 \mathrm{kD}$ were migrated. After the incubation under reducing conditions of $0.35 \mathrm{M}$ DTT, the

215 intensity of the two bands at $\sim 26 \mathrm{kD}$ and one band at $\sim 18 \mathrm{kD}$ substantially increased, and two

216 new bands have appeared above $26 \mathrm{kD}$. Simultaneously, the intensity of band in $\sim 50 \mathrm{kD}$ band

217 diminished considerably. The change from non-reducing to reducing condition was a

218 consequence of intensity shift in a band at $\sim 14 \mathrm{kD}$ towards two intensive bands appeared at

$219 \sim 10 \mathrm{kD}$ and $4 \mathrm{kD}$. Tandem MS analysis and database searching identified nine isomers of

220 cruciferin, and three isomers of napin from Brassica napus (Table 2). The peptides derived

221 from intact napin were not significantly mapped to napin 2SS3 (data not shown) but were

222 significantly fitted to cruciferin CRU4.

223

224 Identification of proteins in ileal digesta

225 Ninety six polypeptide profiles of ileal digesta showed the same pattern of the protein migration

226 across the gels, regardless of rapeseed variety and processing. All protein bands of ileal

227 digesta appeared to be similar to that of the rapeseed proteins obtained under non-reducing

228 conditions. However, mass spectrometric identification of the ileal digesta proteins showed that

229 all the protein bands examined were endogenous chicken enzymes (Figure 2, Table 3). The

230 proteins were identified as trypsin (I-P1, II-P29), chymotrypsin (elastase and precursor) (all $\sim 20$

$231 \mathrm{kDa})$, carboxypeptidase B ( 30 kDa), and $\alpha$-amylase ( 50 kDa). Under non-reducting condition,

232 although the polypeptide profiles showed a similar pattern of these enzymes across all samples

233 of ileal digesta, the ileal digesta of four cold pressed varieties (DK Cabernet, Compass,

234 Sesame, NK Grandia) resulted in slightly lower relative abundance at $10 \mathrm{kDa}$ and $50 \mathrm{kDa}$

235 compared to the ileal digesta of all hexane extracted varieties.

236

237 Discussion

238 
239 The high concentration of methionine and cysteine in the rapeseed co-products might reflect the

240 abundance of sulphide bonds in napin as well as cruciferin (Table 1). However, the content of

241 sulphur-rich amino acids in ileal digesta might potentially derive from indigestible dietary

242 proteins or endogenous enzymes.

243 Both napin and cruciferin are reported as allergenic proteins in rapeseeds and mustards

244 in European Union or Canada (Menendezarias et al., 1990; Palomares et al., 2005;

245 Puumalainen et al., 2015). The allergenicity of the protein has been linked often with its

246 resistance to digestion by hydrolysis enzymes (Untersmayr and Jensen-Jarolim, 2008). Thus,

247 the poor digestibility or allergenicity of rapeseed protein, is considered as a negative factor in

248 the nutritional value of rapeseed co-products either in animal feeds or human diets

249 (Wanasundara, 2011). However, in contrast to many investigations reporting a low digestibility

250 value of CP and amino acids in RSM (Adedokun et al., 2008; Zhou et al., 2013; Kozlowski and

251 Jeroch, 2014; Le et al., 2014; Li et al., 2015) a recent growth performance trial testing RSM

252 resulted in a very similar rates of body weight gain to the control non-rapeseed diet when

253 evaluated in non-ruminants (Parr et al., 2015). This suggests that protein rich co-products might

254 have a good nutritional quality.

255 The digestibility of dietary protein and thus the overall estimation of the nutritional value

256 of protein varies, depending on the protein type, solubility, protein interaction with other

257 components (concentrate vs. food matrix) and type of digestion models (in vitro vs. in vivo) (Ren

258 et al., 2012; Zhang and Vardhanabhuti, 2014; Overduin et al., 2015). Pantoja-Uceda et al.

259 (2004) investigated the structure of the precursor form of the recombinant napin Bnlb (rproBnlb,

2602 albumin) from the seeds of Brassica napus, using an in vitro proteolytic digestion by the

261 standard simulated gastric fluid, and circular dichroism analysis by heat treatment up to $80{ }^{\circ} \mathrm{C}$

262 and cooling to $20^{\circ} \mathrm{C}$. The highly compact and thermal structure of rproBnlb appeared to be a

263 very resistant to digestion, and showed very limited unfolding pattern, recovering after cooling to

$26420^{\circ} \mathrm{C}$. In contrast, the rapeseed cruciferin exhibited a surface hydrophobicity with a low thermal

265 stability (Salleh et al., 2002). Withana-Gamage et al. (2014) tested the Arabidopsis hetero- and

266 homo-hexameric cruciferin forms composed only of CRUA, CRUB or CRUC subunits using

267 simulated gastric fluid degradation kinetics; they showed that all cruciferins were easily cleaved

268 by proteolytic enzyme during the 2 hours, but CRUC was digested at a slower rate than CRUA 
269 and CRUB. A study of Bos et al. (2007) investigating the nutritional value of rapeseed protein

270 isolates using an in vivo digestion model of humans, has reported that both napin and cruciferin

271 were not completely digested in the ileal stage, based only on SDS-PAGE assay.

272 In the current study, the ileal digesta were collected from broiler chickens that were fed

2732 hours prior to sampling. We did not observe any cruciferin or napin in digesta, all the ileal

274 digesta proteins were assigned to endogenous digestive enzymes.

275 Application of SDS-PAGE is often used to illustrate the napin and cruciferin abundance

276 and di-sulphate bond cleavages at different stages of protein degradation using either in vitro or

277 in vivo digestion models (Bos et al., 2007). As the molecular weights of cruciferin and napin, as

278 well as their degradation products, exhibit very similar apparent MWs to that of the digestive

279 enzymes observed (such as a-amylase, chymotrypsin, carboxypeptidase, trypsin, trypsinogen)

280 in SDS-PAGE, the migrated protein bands from ileal digesta might be mismatched and

281 incorrectly assigned to the rapeseed proteins when MS-based identification is not undertaken

282 on ileal samples (Bos et al., 2007; Abeysekara and Wanasundara, 2009; Rommi et al., 2014).

283 The secretion of endogenous enzymes in the gut depends on diet, the animal species

284 and its physiological state (Brzek et al., 2013). The "adaptive modulation hypothesis" describes

285 the course of digestion as a process, in which the activity of digestive enzymes is adjusted to

286 the content of the substrates in the diet, such that animals fully utilize available resources but at

287 the same time do not waste energy on synthesising the excess enzymes (Karasov and

288 Diamond, 1988; Diamond and Hammond, 1992). In the current study, all diets consisted of the

289 same amount of wheat starch, glucose, vitamins and minerals. Although added rapeseed oil

290 was the same between test diets $(50 \mathrm{~g} / \mathrm{kg})$, total rapeseed oil content varied as RSC had

291 greater levels of residual oil than SRSM. Thus, the difference in relative abundance of

292 endogenous enzyme in SDS-PAGE profiles between RSC and SRSM ileal digesta might be

293 mainly due to the different content of CP and oil in diets.

294 An understanding of fate of rapeseed protein and functionality of the digestive system,

295 in terms of secretion of endogenous enzymes, is far from being completely understood across

296 bird species. However, to our knowledge this is the first study showing the lack of presence of

297 rapeseed protein following the changes in abundance of endogenous enzymes in ileal digesta.

298 The evidence of abundance of trypsin/chymotrypsin after feeding low or high protein diets might 
299 explain the reason of a low and varied nutritional value of rapeseed protein often reported

300 (Maison, 2013). The evaluation of nutritional value in dietary protein rich feed, is based on the

301 content of protein in diets, ileal digesta and endogenous protein. Endogenous losses are

302 calculated based on the endogenous proteins that are excreted in the human or animal gastro-

303 intestinal tract after consumption of protein-free diets (Stein et al., 2007). However, when

304 various protein-concentrated diets are tested, the estimation of endogenous and dietary protein

305 is challenging due to almost identical molecular weights between rapeseed protein and

306 endogenous enzyme proteins, and variation in endogenous protein secretion depending on

307 individual components in the diets.

308 To conclude, despite published evidence of in vitro based-experiments describing the low

309 digestibility of rapeseed protein, in the current study napin and cruciferin were not detected in

310 the ileal digesta of broiler chickens regardless of dietary protein content, rapeseed variety and

311 type of oil-extraction process. The absence of rapeseed proteins in the terminal ileum suggests

312 that they could be readily digested. A molecularly based approach, such as using the proteomic

313 tools in the current study, is applicable to investigate the true fate of dietary rapeseed proteins

314 and their dynamics within the entire tract. This will help to further our understanding of in order

315 to measure the nutritional value of rapeseed co-products.

316

\section{Acknowledgements}

318 This work is funded by AHDB Cereals and Oilseeds (RD-2012-3812).

References

321 Abeysekara, S.; Wanasundara, J.P.D., 2009: Prediction of Allergenicity and Digestibility of Brassicaceae seed Meal Proteins - An In Vitro Study. Agriculture and Agri-Food Canada. http://www.australianoilseeds.com [accessible on February 2016].

324

Adedokun, S.A.; Adeola, O.; Parsons, C.M.; Lilburn, M.S.; Applegate, T.J., 2008: Standardized Ileal Amino Acid Digestibility of Plant Feedstuffs in Broiler Chickens and Turkey Poults Using a Nitrogen-Free or Casein Diet. Poultry Science 87, 2535-2548.

AOAC. 1990: Official Methods of Analysis, 13th ed. Washington, DC. 
328

329

330

331

332

333

334

335

336

337

338

339

340

341

342

343

344

345

346

347

348

349

350

351

352

353

354

355

356

Berot, S.; Compoint, J.P.; Larre, C.; Malabat, C.; Gueguen, J., 2005: Large scale purification of rapeseed proteins (Brassica napus L.). Journal of Chromatography B 818, 35-42.

Bos, C.; Airinei, G.; Mariotti, F.; Benamouzig, R.; Berot, S.; Evrard, J.; Fenart, E.; Tome, D.; Gaudichon, C., 2007: The poor digestibility of rapeseed protein is balanced by its very high metabolic utilization in humans. Journal of Nutrition 137, 594-600.

Brzek, P.; Ciminari, M.E.; Kohl, K.D.; Lessner, K.; Karasov, W.H.; Caviedes-Vidal, E., 2013: Effect of age and diet composition on activity of pancreatic enzymes in birds. Journal of Comparative Physiolology B 183, 685-697.

Diamond, J.; Hammond, K., 1992: The Matches, Achieved by Natural-Selection, between Biological Capacities and Their Natural Loads. Experientia 48, 551-557.

EN ISO, 1997: Determination of oil content - Method using continuous-wave low-resolution nuclear magnetic resonance spectrometry (Rapid method). BS EN ISO 5511.

Kasprzak, M.M.; Houdijk, J.G.M.; Kightley, S.; Olukosi, O.A.; White, G.A.; Carre, P.; Wiseman, J., 2016: Effects of rapeseed variety and oil extraction method on the content and ileal digestibility of crude protein and amino acids in rapeseed cake and softly processed rapeseed meal fed to broiler chickens. Animal Feed Science and Technology 213, 9098.

Karasov, W.H.; Diamond, J.M., 1988: Interplay between Physiology and Ecology in Digestion. Bioscience 38, 602-611.

Kozlowski, K.; Jeroch, H., 2014: Enhancing the Nutritional Value of Poultry Feedstuffs Using the Example of Rapeseed Products - a Review. Annals of Animal Science 14, 245-256.

Le, M.H.A.; Landero, J.L.; Beltranena, E.; Zijlstra, R.T., 2014: The effect of feeding increasing inclusion of extruded Brassica juncea canola expeller on growth performance and nutrient digestibility in weaned pigs. Animal Feed Science and Technology 192, 73-80.

Li, P.L.; Wang, F.L.; Wu, F.; Wang, J.R.; Liu, L.; Lai, C.H., 2015: Chemical composition, energy and amino acid digestibility in double-low rapeseed meal fed to growing pigs. Journal of Animal Science and Biotechnology 6, 1-10.

Llames, C.R.; Fontaine, J., 1994: Determination of Amino-Acids in Feeds - Collaborative Study. Journal of AOAC International 77, 1362-1402. 
357

358

359

360

361

362

363

364

365

366

367

368

369

370

371

372

373

374

375

376

377

378

379

380

381

382

383

384

385

386

Maison, T.; Stein, H.H., 2014: Digestibility by growing pigs of amino acids in canola meal from North America and 00-rapeseed meal and 00-rapeseed expellers from Europe. Journal of Animal Science 92, 3502-14.

Maison, T., 2013: Evaluation of the nutritional value of canola meal, 00-rapeseed meal and 00rapeseed expellers fed to pigs. PhD dissertation in Animal Sciences. University of Illinois, Urbana-Champaign.

Menendezarias, L.; Dominguez, J.; Moneo, I.; Rodriguez, R., 1990: Epitope Mapping of the Major Allergen from Yellow Mustard Seeds, Sin-a-I. Molecular Immunology 27, 143150.

Murtagh, G.J.; Archer, D.B.; Dumoulin, M.; Ridout, S.; Matthews, S.; Arshad, S.H.; Alcocer, M.J.C., 2003: In vitro stability and immunoreactivity of the native and recombinant plant food 2S albumins Ber e 1 and SFA-8. Clinical and Experimental Allergy 33, 1147-1152.

Overduin, J.; Guerin-Deremaux, L.; Wils, D.; Lambers, T.T., 2015: NUTRALYS (R) pea protein: characterization of in vitro gastric digestion and in vivo gastrointestinal peptide responses relevant to satiety. Food \& Nutrition Research 59, 1-9.

Palomares, O.; Cuesta-Herranz, J.; Vereda, A.; Sirvent, S.; Villalba, M.; Rodriguez, R., 2005: Isolation and identification of an $11 \mathrm{~S}$ globulin as a new major allergen in mustard seeds. Annals of Allergy, Asthma \& Immunology 94, 586-592.

Pantoja-Uceda, D.; Palomares, O.; Bruix, M.; Villalba, M.; Rodriguez, R.; Rico, M.; Santoro, J., 2004: Solution structure and stability against digestion of rproBnlb, a recombinant $2 S$ albumin from rapeseed: Relationship to its allergenic properties. Biochemistry $\mathbf{4 3 ,}$ 16036-16045.

Parr, C.K.; Liu, Y.; Parsons, C.M.; Stein, H.H., 2015: Effects of high-protein or conventional canola meal on growth performance, organ weights, bone ash, and blood characteristics of weanling pigs. Journal of Animal Science 93, 2165-2173.

Puumalainen, T.J.; Puustinen, A.; Poikonen, S.; Turjanmaa, K.; Palosuo, T.; Vaali, K., 2015: Proteomic identification of allergenic seed proteins, napin and cruciferin, from coldpressed rapeseed oils. Food Chemistry 175, 381-385.

Rask, L.; Ellerström, M.; Ezcurra, I.; Stålberg, K.; Wycliffe, P., 1998: Seed-specific regulation of the napin promoter in Brassica napus. Journal of Plant Physiology 152, 595-599. 
Ren, L.Q.; Zhao, F.; Tan, H.Z.; Zhao, J.T.; Zhang, J.Z.; Zhang, H.F., 2012: Effects of dietary protein source on the digestive enzyme activities and electrolyte composition in the small intestinal fluid of chickens. Poultry Science 91, 1641-6.

Rommi, K.; Hakala, T.K.; Holopainen, U.; Nordlund, E.; Poutanen, K.; Lantto, R., 2014: Effect of Enzyme-Aided Cell Wall Disintegration on Protein Extractability from Intact and Dehulled Rapeseed (Brassica rapa L. and Brassica napus L.) Press Cakes. Journal of Agricultural and Food Chemistry 62, 7989-7997.

Salleh, M.R.B.M.; Maruyama, N.; Adachi, M.; Hontani, N.; Saka, S.; Kato, N.; Okawa, Y.; Utsumi, S., 2002: Comparison of protein chemical and physicochemical properties of rapeseed cruciferin with those of soybean glycinin. Journal of Agricultural and Food Chemistry 50, 7380-7385.

Savoie, L.; Galibois, I.; Parent, G.; Charbonneau, R., 1988: Sequential Release of Amino-Acids and Peptides during In vitro Digestion of Casein and Rapeseed Proteins. Nutrition Research 8, 1319-1326.

Schatzki, J.; Ecke, W.; Becker, H.C.; Mollers, C., 2014: Mapping of QTL for the seed storage proteins cruciferin and napin in a winter oilseed rape doubled haploid population and their inheritance in relation to other seed traits. Theoretical and Applied Genetics 127, 1213-22.

Seneviratne, R.W.; Beltranena, E.; Goonewardene, L.A.; Zijlstra, R.T., 2011: Effect of crude glycerol combined with solvent-extracted or expeller-pressed canola meal on growth performance and diet nutrient digestibility of weaned pigs. Animal Feed Science and Technology 170, 105-110.

Seneviratne, R.W.; Beltranena, E.; Newkirk, R.W.; Goonewardene, L.A.; Zijlstra, R.T., 2011: Processing conditions affect nutrient digestibility of cold-pressed canola cake for grower pigs. Journal of Animal Science 89, 2452-2461.

Stein, H.H.; Seve, B.; Fuller, M.F.; Moughan, P.J.; de Lange, C.F.M., 2007: Invited review: Amino acid bioavailability and digestibility in pig feed ingredients: Terminology and application. Journal of Animal Science 85, 172-180.

Untersmayr, E.; Jensen-Jarolim, E., 2008: The role of protein digestibility and antacids on food allergy outcomes. Journal of Allergy and Clinical Immunology 121, 1301-1308. 
417 Wanasundara, J.P.D.; Mclntosh, T.C., 2013: Process of aqueous protein extraction from

$418 \quad$ Brassicaceae oilseeds. Patent US 8557963B2.

419 Wanasundara, J.P.D., 2011: Proteins of Brassicaceae Oilseeds and their Potential as a Plant

$420 \quad$ Protein Source. Critical Reviews in Food Science and Nutrition 51, 635-677.

421 Wickramasuriya, S.S.; Yi, Y.J.; Yoo, J.; Kang, N.K.; Heo, J.M., 2015: A review of canola meal as

422 an alternative feed ingredient for ducks. Journal of Animal Science and Technology 57,

$423 \quad 1-9$.

424 Withana-Gamage, T.; Hegedus, D.; Qiu, X.; Wanasundara, J., 2014: Solubility, Heat-Induced

425 Gelation and Pepsin Susceptibility of Cruciferin Protein as Affected by Subunit

426 Composition. Food Biophysics 10, 1-13.

427 Zhang, S.; Vardhanabhuti, B., 2014: Effect of initial protein concentration and pH on in vitro 428 gastric digestion of heated whey proteins. Food Chemistry 145, 473-480.

429 Zhou, X.; Oryschak, M.A.; Zijlstra, R.T.; Beltranena, E., 2013: Effects of feeding high- and low430 fibre fractions of air-classified, solvent-extracted canola meal on diet nutrient digestibility 431 and growth performance of weaned pigs. Animal Feed Science and Technology 179, 432 112-120.

433

434

435

436 
1 Table 1. Concentration of crude protein and sulphur- rich amino acids in rapeseed co-products and ileal digesta (g/kg dry matter)

\begin{tabular}{|c|c|c|c|c|c|c|c|c|c|c|}
\hline \multirow{2}{*}{ Rapeseed variety } & \multirow{2}{*}{ DM } & \multicolumn{4}{|c|}{ Rapeseed co-products } & \multirow[b]{2}{*}{ Oil } & \multicolumn{4}{|c|}{ Ileal digesta } \\
\hline & & Met & Cys & TAA & $\mathrm{CP}$ & & Met & Cys & TAA & $\mathrm{CP}$ \\
\hline \multicolumn{11}{|l|}{ Rapeseed cake } \\
\hline Compass & 899 & 5.7 & 10.5 & 255.8 & 293.2 & 259.6 & 1.0 & 5.7 & 84.8 & 109.1 \\
\hline Sesame & 890 & 6.5 & 14.1 & 292.8 & 331.8 & 293.0 & 1.1 & 6.1 & 86.6 & 110.6 \\
\hline NK Grandia & 892 & 6.8 & 14.3 & 302.9 & 335.0 & 268.9 & 1.0 & 6.0 & 83.3 & 111.7 \\
\hline DK Cabernet & 881 & 6.5 & 16.8 & 305.0 & 339.7 & 292.5 & 1.2 & 6.2 & 90.7 & 114.5 \\
\hline Mean & 890 & 6.4 & 13.9 & 289.1 & 324.9 & 278.5 & 1.1 & 6.0 & 86.4 & 111.5 \\
\hline SE & 3.6 & 0.24 & 1.28 & 11.41 & 10.71 & 8.46 & 0.03 & 0.10 & 1.60 & 1.13 \\
\hline \multicolumn{11}{|l|}{ Soft rapeseed meals } \\
\hline DK Cabernet1* & 866 & 8.8 & 19.0 & 395.5 & 418.6 & 30.8 & 1.4 & 7.9 & 113.8 & 137.7 \\
\hline DK Cabernet2* & 864 & 9.1 & 19.2 & 411.3 & 456.9 & 31.2 & 1.5 & 8.9 & 120.8 & 155.5 \\
\hline Quartz & 866 & 9.1 & 18.8 & 400.4 & 430.4 & 31.9 & 1.7 & 8.9 & 128.9 & 162.3 \\
\hline Trinity & 868 & 8.8 & 19.9 & 399.1 & 442.8 & 33.7 & 1.3 & 7.3 & 105.7 & 133.9 \\
\hline Compass & 848 & 7.8 & 16.7 & 385.8 & 467.5 & 30.4 & 1.4 & 6.6 & 105.0 & 130.8 \\
\hline Incentive & 853 & 9.4 & 18.6 & 439.8 & 469.1 & 34.7 & 1.6 & 8.6 & 128.0 & 163.7 \\
\hline Excalibur & 833 & 9.4 & 21.2 & 429.6 & 494.8 & 30.3 & 1.5 & 9.4 & 125.5 & 158.6 \\
\hline Avatar & 856 & 9.0 & 19.2 & 409.8 & 495.1 & 38.4 & 1.8 & 8.4 & 127.3 & 146.5 \\
\hline PR46W21 & 822 & 9.9 & 23.7 & 452.9 & 507.3 & 35.6 & 1.5 & 7.8 & 112.4 & 139.0 \\
\hline Palmedor & 859 & 9.9 & 20.9 & 450.5 & 516.7 & 28.2 & 1.5 & 7.3 & 114.2 & 145.2 \\
\hline L2750L & 838 & 9.6 & 20.9 & 444.4 & 521.2 & 44.8 & 1.6 & 8.4 & 119.7 & 148.8 \\
\hline Ability & 821 & 8.9 & 21.7 & 456.5 & 560.2 & 48.1 & 1.7 & 8.0 & 121.7 & 149.9 \\
\hline Mean & 849 & 9.1 & 20.0 & 423.0 & 481.7 & 34.8 & 1.5 & 8.1 & 118.6 & 147.6 \\
\hline SE & 5.0 & 0.16 & 0.53 & 7.33 & 12.01 & 1.76 & 0.04 & 0.23 & 2.41 & 3.15 \\
\hline
\end{tabular}

2 DM, dry matter; Cys, cysteine; Met, methionine; TAA, total amino acids; CP, crude protein; SE, standard error. 
3 * A variety of DK Cabernet was grown on two different farms and further processed by hexane extraction.

4

5

6

7

8

9

10

11

12

13

14

15

16

17

18

19

20 
Table 2. Identified proteins in rapeseed co-products

\begin{tabular}{|c|c|c|c|c|c|c|c|}
\hline Band ID & Identification & Taxonomy & Accession number & $\begin{array}{l}\text { Mascot } \\
\text { score }\end{array}$ & $\begin{array}{l}\text { Matched } \\
\text { peptides }\end{array}$ & $\begin{array}{l}\text { Matched } \\
\text { sequences }\end{array}$ & $\begin{array}{c}\text { Sequence } \\
\text { coverage (\%) }\end{array}$ \\
\hline \multirow{2}{*}{ CRU_n } & Cruciferin $\mathrm{BnC} 1$ & B.napus & CRU1_BRANA & 576 & 14 & 6 & 25 \\
\hline & Cruciferin CRU1 & B.napus & CRU3_BRANA & 452 & 12 & 5 & 17 \\
\hline CRU_r & Cruciferin CRU4 & B.napus & CRU4_BRANA & 418 & 11 & 5 & 18 \\
\hline \multirow{3}{*}{ a CRU_n1 } & Cruciferin $\mathrm{BnC} 1$ & B.napus & CRU1_BRANA & 546 & 8 & 6 & 26 \\
\hline & Cruciferin CRU1 & B.napus & CRU3_BRANA & 336 & 6 & 3 & 12 \\
\hline & Cruciferin CRU4 & B.napus & CRU4_BRANA & 330 & 4 & 3 & 20 \\
\hline a CRU_n2 & Cruciferin CRU4 & B.napus & CRU4_BRANA & 534 & 18 & 7 & 23 \\
\hline \multirow{4}{*}{ a CRU_r2 } & Cruciferin CRU1 & B.napus & 461840 & 481 & 3 & 3 & 25 \\
\hline & Cruciferin subunit/BnaC01g09900D & B.napus & $12751302 / 674894422$ & $468 / 468$ & $3 / 3$ & $3 / 3$ & $26 / 26$ \\
\hline & BnaA09g04300D & B.napus & 674913375 & 364 & 3 & 3 & 21 \\
\hline & BnaA08g13680D & B.napus & 674918950 & 256 & 2 & 2 & 9 \\
\hline
\end{tabular}


Table 2. Identified proteins in rapeseed co-products (continued)

\begin{tabular}{|c|c|c|c|c|c|c|c|}
\hline Band ID & Identification & Taxonomy & Accession number & $\begin{array}{l}\text { Mascot } \\
\text { score }\end{array}$ & $\begin{array}{l}\text { Matched } \\
\text { peptides }\end{array}$ & $\begin{array}{l}\text { Matched } \\
\text { sequences }\end{array}$ & $\begin{array}{c}\text { Sequence } \\
\text { coverage (\%) }\end{array}$ \\
\hline \multirow{2}{*}{ a CRU_r3 } & Cruciferin CRU4 & B.napus & CRU4_BRANA & 331 & 4 & 2 & 18 \\
\hline & Cruciferin $\mathrm{BnC} 1$ & B.napus & CRU1_BRANA & 278 & 6 & 4 & 12 \\
\hline a CRU_r4 & Cruciferin CRU4 & B.napus & CRU4_BRANA & 355 & 8 & 6 & 20 \\
\hline \multirow{2}{*}{$\beta C R U \_n$} & Cruciferin CRU4 & B.napus & CRU4_BRANA & 598 & 21 & 4 & 23 \\
\hline & Cruciferin CRU1 & B.napus & CRU3_BRANA & 237 & 4 & 3 & 7 \\
\hline \multirow{2}{*}{$\beta C R U \_r$} & Cruciferin CRU1 & B.napus & CRU3_BRANA & 402 & 11 & 5 & 18 \\
\hline & Cruciferin CRU4 & B.napus & CRU4_BRANA & 387 & 7 & 3 & 16 \\
\hline Nap & Cruciferin CRU4 & B.napus & CRU4_BRANA & 375 & 6 & 4 & 20 \\
\hline Nap L & napin-3/large peptide & B.napus & 2SS3_BRANA & 335 & 7 & 2 & 58 \\
\hline Nap S & napin 3 & B.napus & 2SS3 BRANA & 170 & 1 & 1 & 27 \\
\hline
\end{tabular}


Table 3. Identified proteins in ileal digesta

\begin{tabular}{|c|c|c|c|c|c|c|c|}
\hline ID Band & Identification & Taxonomy & Accession number & $\begin{array}{c}\text { Mascot } \\
\text { Score }\end{array}$ & $\begin{array}{l}\text { Matched } \\
\text { peptides }\end{array}$ & $\begin{array}{l}\text { Matched } \\
\text { sequences }\end{array}$ & $\begin{array}{c}\text { Sequence } \\
\text { coverage (\%) }\end{array}$ \\
\hline Carb & $\begin{array}{l}\text { Carboxypeptidase B } \\
\text { preproprotein }\end{array}$ & Gallus gallus & 476007880 & 681 & 7 & 6 & 38 \\
\hline ChymTryp & $\begin{array}{l}\text { Chymotrypsin-like elastase } \\
\text { family member } 2 A \text { precursor }\end{array}$ & Gallus gallus & 157817197 & 461 & 5 & 4 & 40 \\
\hline \multirow{2}{*}{ Tryp } & Trypsin II-P29 & Gallus gallus & TRY3_CHICK & 381 & 10 & 4 & 36 \\
\hline & Trypsin I-P1 & Gallus gallus & TRY1_CHICK & 267 & 3 & 3 & 31 \\
\hline
\end{tabular}

43 Mascot score, is derived from the ions scores for all the matched peptides. Number of matched peptides and matched sequences, is a number of significantly

44 peptides/sequences associated with protein identified by Mascot. Percentage coverage, is percentage of the database sequence entry that is covered by the

45 peptides matched to the Mascot data. Mascot scores in italics and non-italics indicate NCBInr and SwissProt scores, respectively. 
1 Figure 1. SDS-PAGE profiles of rapeseed proteins extracted from rapeseed cake and meal.
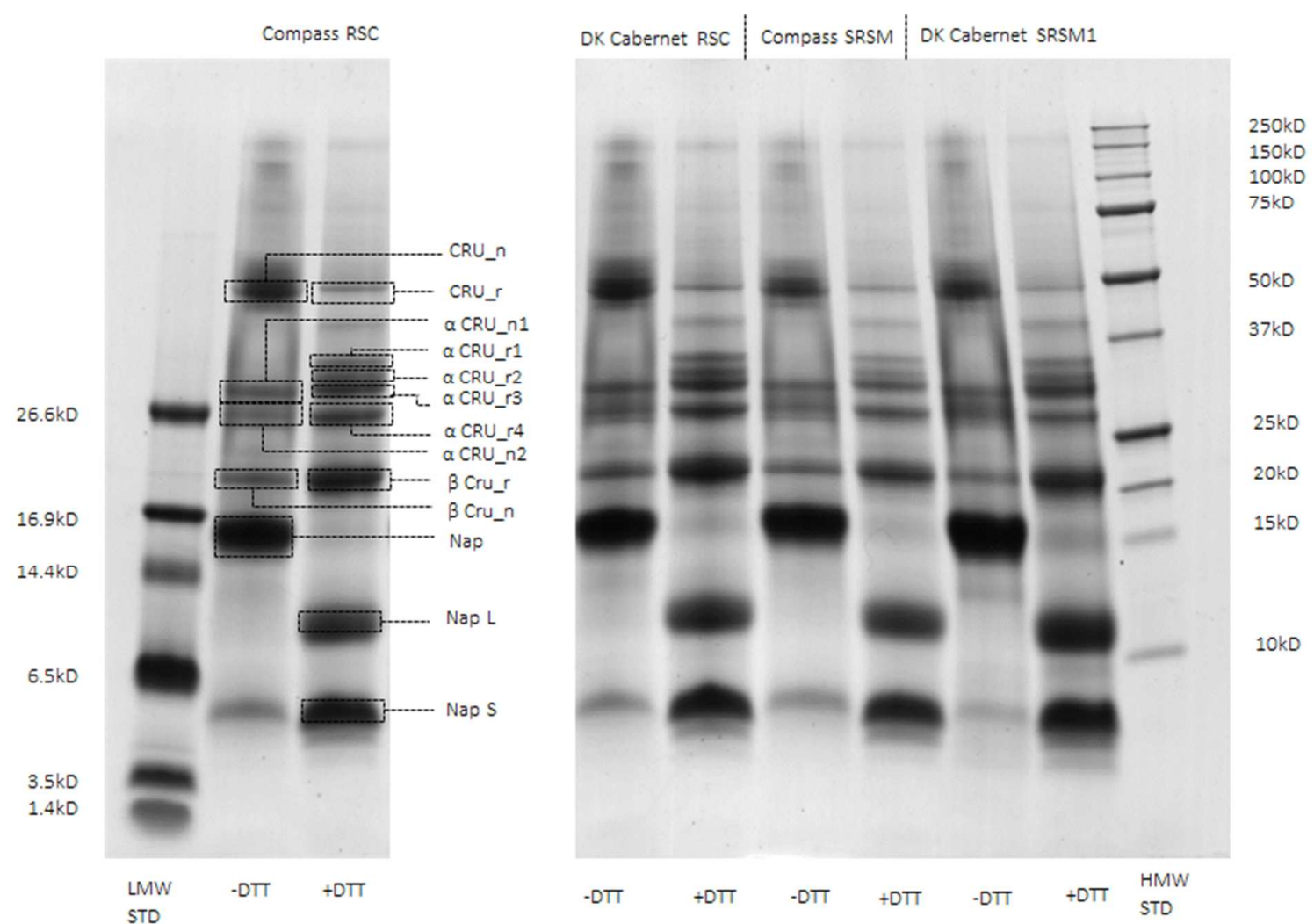

3 RSC, rapeseed cake; SRSM, soft rapeseed meal; LMW STD, low molecular weight standard (1.4, 3.5, 6.5, 14.4, 16.9 and 26.6 kDa); HMW STD, high

4 molecular weight standard $(10,15,20,25,37,50,75,100,150$ and $250 \mathrm{kDa})$; DTT, dithiothreitol, indicating that sample was analysed with (+DTT) or without 5 (-DTT). 
6 Figure 2. SDS-PAGE profile of proteins extracted from ileal digesta after feeding with two rapeseed cake and soft rapeseed meal (Compass and DK 7 Cabernet1).
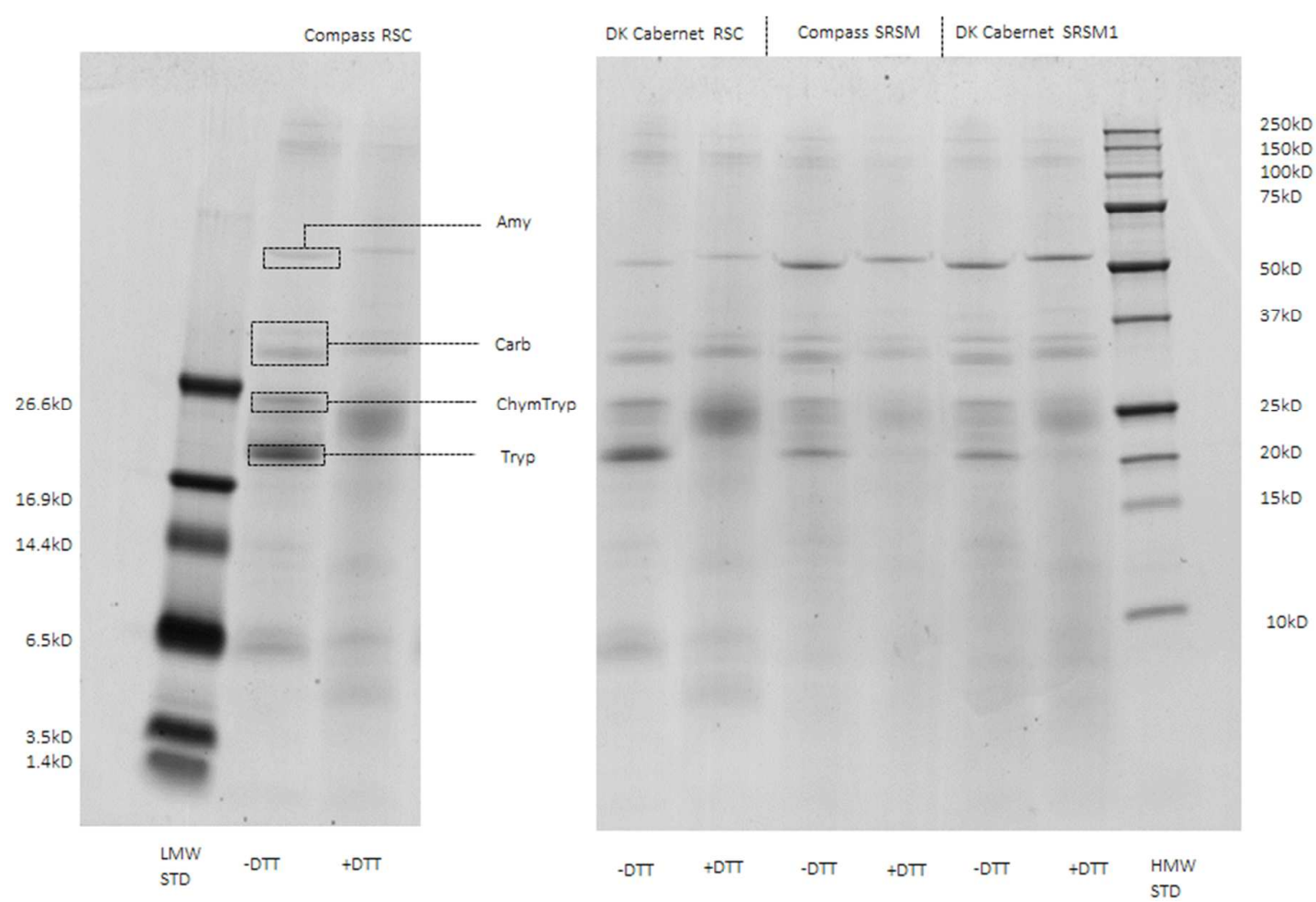

RSC, rapeseed cake; SRSM, soft rapeseed meal; LMW STD, low molecular weight standard (1.4, 3.5, 6.5, 14.4, 16.9 and 26.6 kDa); HMW STD, high

(-DTT). 